University of Nebraska - Lincoln

DigitalCommons@University of Nebraska - Lincoln

July 2007

\title{
Hunter-gatherer Use of Small Animal Food Resources: Coprolite Evidence
}

Karl J. Reinhard

University of Nebraska at Lincoln, kreinhard1@mac.com

J. R. Ambler

Flagstaff, Arizona

C. R. Szuter

University of Arizona Press

Follow this and additional works at: https://digitalcommons.unl.edu/natrespapers

Part of the Natural Resources and Conservation Commons

Reinhard, Karl J.; Ambler, J. R.; and Szuter, C. R., "Hunter-gatherer Use of Small Animal Food Resources: Coprolite Evidence" (2007). Papers in Natural Resources. 73.

https://digitalcommons.unl.edu/natrespapers/73

This Article is brought to you for free and open access by the Natural Resources, School of at DigitalCommons@University of Nebraska - Lincoln. It has been accepted for inclusion in Papers in Natural Resources by an authorized administrator of DigitalCommons@University of Nebraska - Lincoln. 
This is a preprint of an article published in International Journal of Osteoarchaeology 17:4 (2007), pp. 416-428;

doi 10.1002/oa.883 Copyright (C) 2006 John Wiley \& Sons, Ltd. Used by permission.

http://www3.interscience.wiley.com/journal/5488/home

Submitted May 11, 2005; revised March 21, 2006; accepted May 30, 2006; published online December 20, 2006

\title{
Hunter-gatherer Use of Small Animal Food Resources: Coprolite Evidence
}

\author{
K. J. Reinhard ${ }^{1, *}$, J. R. Ambler ${ }^{2}$, and C. R. Szuter ${ }^{3}$ \\ ${ }^{1}$ School of Natural Resources, 309 Biochemistry Hall, University of Nebraska-Lincoln, Lincoln, NE 68583-0758, USA \\ 26510 N. Bader Road, Flagstaff, Arizona 86001, USA \\ 3 University of Arizona Press, 355 S. Euclid Ave., Suite 103, Tucson, AZ 85719, USA \\ * Corresponding author - K. J. Reinhard, School of Natural Resources, 309 Biochemistry Hall, University of Nebraska-Lincoln, \\ Lincoln, NE 68583-0758, USA. email — kreinhard1@unl.edu
}

\begin{abstract}
Faunal remains are commonly found in coprolites and provide direct evidence of animal consumption. An evaluation of hunter-gatherer coprolites from the Southwest United States shows that animal bone in coprolites can be used to assess patterns of hunting, food preparation, and general importance of small animals in diet. This is demonstrated by a comparison of faunal assemblages between two hunter-gatherer sites with respect to small animal hunting strategies. The sites are Dust Devil Cave on the Colorado Plateau, an Archaic winter habitation, and Hinds Cave, a warm season Archaic habitation in the lower Pecos of Texas. The results indicate that small animal hunting varied regionally and seasonally.
\end{abstract}

Keywords: Southwest, zooarcheology, coprolite, hunter-gatherer, paleonutrition

\section{Introduction}

Remains of small animals have been noted in human coprolites throughout the history of coprolite research (Callen \& Cameron, 1960; Heizer, 1967; Rhone, 1971; Hall, 1972; Fry, 1977, 1980; Sobolik, 1988, 1993; Reinhard, 1992; Reinhard \& Bryant, 1992a; Hansen, 1994; Reinhard et al., 2002). The consistent presence of bone in coprolites provides strong potential for the comparative study of small vertebrate exploitation among prehistoric peoples. In the United States, coprolite context bones have been largely ignored in the reconstruction of subsistence, due in part to the variable preservation of bones between sites and variable means of reporting the finds. However, small animal bones provide insight into hunting patterns, seasonality, food prep- aration techniques, and culinary selectivity for certain portions of the prey animals. In addition, the comparability of zooarcheological data between coprolite and non-coprolite contexts at the same site can be assessed. These topics are examined below for huntergatherer sites in the Southwest United States.

\section{Methodological considerations}

Historically, botanical remains have been emphasized in coprolite research. This was due to stronger training in botany than zoology among many coprolite analysts (Callen, 1963; Hall, 1972; Bryant, 1974a,b; Bryant \& Williams-Dean, 1975; Fry, 1977, 1985; Stiger, 1977; Williams-Dean, 1978; Scott, 1979; Clary, 1983, 1984; Stock, 1983; Aasen, 1984; Holloway, 1985; Hansen, 
1994). Therefore, analysts have not traditionally had the background to use bones found in coprolites as interpretative tools. In contrast, where archaeologists have been involved in directing coprolite research, a more holistic approach is seen which includes detailed analysis of bone. This is exemplified by Shafer's direction of the analysis of lower Pecos coprolites (Shafer \& Bryant, 1977; Williams-Dean, 1978), Ambler's (1984) direction of the analysis of Dust Devil Cave coprolites (Reinhard, 1985a; Van Ness, 1986), and Heizer's (1967) direction of the study of Lovelock Cave.

Variation of bone preservation sometimes hinders zooarcheological analysis. The bone preservation from Lovelock Cave (Heizer, 1967; Heizer \& Napton, 1969), Dust Devil Cave (Czaplewski, 1985) and Hinds Cave (Williams-Dean, 1978) was good enough to allow for genus identification of many bone fragments. However, the poor preservation of bone in coprolites from Danger Cave and Hogup Cave (Fry, 1977) precluded identification of most bone fragments to any taxonomic level. Bone preservation is affected by the preparation of animals that were consumed, the chemistry of the intestinal tracts, and the post-defecation environment. In some cases bone in coprolites is fragmented into small pieces, probably before consumption of the prey item. Also, digestion dissolves bone. Experiments with the consumption and defecation of small fish bones show that a large share of bone is dissolved in the stomach and intestine (Jones, 1986). Mammalian bones can also be fully digested, as shown by Crandall and Stahl (1995). The environment into which the bones are defecated can further affect bone. Bones from coprolites found in open sites are typified by poor preservation, probably due to the chemistry of latrine environments and water percolation through the coprolites. In general, bone preservation from coprolites is best if the coprolites are from dry, protected sites.

For hunter-gatherer coprolites, differences in the reporting styles of various coprolite analysts hinder comparative studies. For example, Czaplewski (1985: 11519) presented bone tabulations of Dust Devil Cave coprolites by individual element per coprolite. Consequently one can go to this analysis and determine the kind and minimum number of animals represented, as well as the portions of animals that were eaten. Williams-Dean (1978) presented the taxa present in each coprolite, but did not break the data down into description of elements. Heizer and Napton (1969) presented the number of taxa present in the total number of coprolites, but did not describe the bones from each coprolite. Fry (1977) presented most of his data in terms of percentage of bone weight per coprolite. Clearly, techniques of identification and quantification are not standardized, and consequently a comparison of all of these sites at the same level of analysis is difficult.

The vast majority of coprolites contain only small animal bones, or small bones from large animals (Reinhard, 1992; Sobolik, 1993). Only one researcher (Reinhard, 1988, 1992) reported finding a larger skeletal element from a large animal, this being a deer vertebral centrum in a human coprolite from Salmon Ruin, an ancestral Pueblo site in New Mexico. In contrast, zooarcheological studies of bone excavated from noncoprolite contexts in southwestern United States sites emphasize large animals. Even quarter-inch screens are not fine enough to recover many small bones, especially fragmented bone (Szuter, 1991: 49-55). In addition, small bones are often thought to be intrusive in archaeological deposits. There are exceptions, such as Haury's (1976) identification of small animal bone fragments which he feels passed through digestive systems before being incorporated in Hohokam middens. Nevertheless, small animals tend to be overlooked in many zooarcheological studies.

\section{Overview of hunter-gatherer studies}

Bone analyses for coprolites recovered from huntergatherer sites are summarized in Table 1. These data were derived from interdisciplinary analyses of coprolites from Lovelock Cave in western Nevada (Heizer, 1967), Hinds Cave in western Texas (Williams-Dean, 1978) and Dust Devil Cave in southern Utah (Lindsay et al., 1968; Ambler, 1984; Reinhard et al., 1985).

Interpreting the actual number of coprolites containing bone is difficult with the Lovelock Cave data. 
Table 1. Frequencies of bone recovered from huntergatherer sites expressed as percentages

\begin{tabular}{llc}
\hline Site & $n$ & $\%$ with bone \\
\hline Lovelock Cave & $31 / 51$ & $61 \%$ \\
Hogup Cave & $36 / 51$ & $71 \%$ \\
Danger Cave & $31 / 46$ & $67 \%$ \\
Great Basin Fremont & $3 / 6$ & $50 \%$ \\
Great Basin Shoshoni & $3 / 3$ & $100 \%$ \\
Dust Devil Cave & $58 / 100$ & $58 \%$ \\
Hinds Cave & $97 / 100$ & $97 \%$ \\
\hline
\end{tabular}

The bone data from this site are tabulated by taxon (Heizer \& Napton, 1969). Consequently, the numbers of coprolites containing a given taxon can be determined, but because two or more taxa can occur in a single coprolite, the actual number of coprolites containing bone is inflated. To determine the number of coprolites containing bone, we referred to Roust's (1967) preliminary report. This report documented 23 coprolites containing fish bone, four containing bird bone, two containing both fish and mammal bone, and two containing only mammal bone. Thus 31 of 51 coprolites contain bone. The taxa represented are listed by Heizer and Napton (1969). The fish species present are Catostomas tahoensis, Gila bicolor and Rhinichthys osculus. The birds include Anas spp. and Fulica americana. Lepus americanus is the only mammal represented.

In Danger Cave and Hogup Caves, Archaic, Fremont and Shoshoni period coprolites were recovered (Fry, 1977). The bones are not identified to any taxonomic level. Of the Archaic coprolites from the caves, 67 of 97 coprolites contained bone. Three out of six Fremont coprolites contained bone, as well as three out of three Shoshoni coprolites. Dust Devil Cave provided the only Archaic coprolites from the Colorado Plateau for which there are quantified zoological data identified by skeletal element (Czaplewski, 1985). Of 100 coprolites analyzed, 58 contained bone. The taxa recovered will be examined in detail in a comparison with Hinds Cave below, but it is necessary to note that the main taxon present was Sylvilagus.

Hinds Cave exhibits the highest incidence of bone in coprolites of any site examined to date: 97 out of 100 coprolites contained bone (Williams-Dean, 1978).
A large variety of taxa are present: 16 small animal taxa are present, representing birds, reptiles, fish and mammals. This is the most diverse spectrum of food animals found in any prehistoric coprolite sample in the world.

Overall, food animals present in the hunter-gatherer coprolites reflect the general ecological conditions in which small animals were hunted. The people who used Lovelock Cave clearly hunted wetland species of fowl and fish. The people who used Dust Devil Cave had a more restricted terrestrial animal diet largely dependent on Sylvilagus. Those at Hinds Cave hunted a diverse range of small vertebrates from terrestrial and aquatic environments.

The analyses of bones from the coprolites of Hinds Cave and Dust Devil Cave are most comparable. The environments surrounding the caves provide a diversity of niches for hunting. Aside from the distance separating them, many factors indicate that Hinds Cave and Dust Devil Cave are comparable largely on the level of general foraging behavior. They are both in a patchwork environment, but Hinds Cave was occupied during the summer when food was plentiful, whereas Dust Devil Cave was utilized during the lean part of the year, the winter. Both sites were chosen for the shelter that the caves provided: Hinds Cave to avoid summer heat and Dust Devil Cave to avoid the winter cold. This interpretation is based on analysis of midden debris, supported by studying the bones found in coprolites, which provide direct evidence of animal procurement and consumption. The bone evidence strongly supports seasonal inferences of cave occupation.

\section{Methodological considerations: Dust Devil and Hinds Caves}

One mundane but important consideration in coprolite analysis is the determination of human origin. The importance in identifying human origin was brought to the forefront in analyses of purported cannibal coprolites (Billman et al., 2000; Dongoske et al., 2000; Lambert et al., 2000; Marlar et al., 2000). This is especially true in this study because we present the facts that animal bone, hair, and intestinal residue were found in human coprolites. The reader may 
well wonder whether or not the coprolites from Dust Devil Cave and Hinds Cave are indeed human. Therefore, determination of biological origin of the coprolites must be discussed.

Many authors have addressed the issue of determination of coprolite human origin (Moore et al., 1969; Bryant, 1974a,b; Bryant \& Williams-Dean, 1975; Fry, 1977; Reinhard, 1985a; Reinhard et al., 1986; Reinhard \& Bryant, 1992a; Marlar et al., 2000; Poiner et al., 2001; Chame, 2003; Guerra et al., 2003; Iñiguez et al., 2003a,b). At the point of discovery, provenance can be used to infer human origin. The discovery of distinct latrines, for example, is suggestive that the coprolites they contain are human. In the first stage of analysis, when the coprolites are sorted, morphological examination can sort out the vast majority of animal feces from human feces (Chame, 2003). Using a field guide of animal feces is very helpful at this stage. However, dog feces can easily be confused with human feces (Reinhard, 1985a,b; Reinhard et al., 1986). This confusion can be resolved. Analysis of dog coprolites reveals that the rehydration color of dog coprolites tends to be light, and they contain fragments of dog hair, dog parasites, soil, and strange inclusions such as cordage, rabbit fur robe fragments, and other items that were apparently consumed from refuse (Reinhard, 1985a,b; Reinhard \& Bryant, 1992a; Reinhard et al., 1986). Most recently, Guerra et al. (2003) presented a method of analyzing the species-specific mites that become incorporated in animal coprolites by grooming. This new line of research will develop into a valuable tool for identifying coprolite zoological origin. Many authors address the importance of evidence of cooking in human coprolites (Moore et al., 1969; Fry, 1977; Reinhard \& Bryant, 1992a). Charcoal, parched seeds, scorched cactus epidermis, and other signs of cooking verify human origin. Foods that require extensive harvesting and preparation such as agave and yucca hearts or cakes of harvested seeds indicate human origin. Biochemical analysis of proteins (Marlar et al., 2000) and molecular biological analysis of DNA (Poinar et al., 2001) are also very useful in determining human origin. Finally, microscopic and molecular biological analyses for human-specific parasites can confirm human origin (Iñiguez et al., 2003a,b).
At Dust Devil Cave and Hinds Cave, the coprolites were found in defined latrine areas. Fecal morphology is consistent with humans. For Dust Devil Cave, harvested and parched Chenopodium and Sporobolis seeds were abundant dietary constituents, and in the same coprolites that contained animal bone (Reinhard, 1985a; Reinhard et al., 1985; Van Ness, 1986). Heat-treated Yucca and Opuntia epidermis were also very common and in the same coprolites that contained bone (Reinhard, 1985a; Reinhard et al., 1985; Van Ness, 1986). Reinhard and Danielson (2005) found that agave and/or yucca phytoliths were present in all the Hinds Cave and Dust Devil Cave coprolites. Williams-Dean (1978; Bryant \& Williams-Dean, 1975) found a diversity of plant macrofossils and microfossils in the Hinds Cave diet consistent with human behavior. This indicates that humans at the site ate plants that had to be harvested and cooked. In addition, the coprolites matched the characteristics identified as human by Fry (1977) such as odor and rehydration color. In parasitological analyses of the coprolites (Williams-Dean, 1978; Reinhard, 1985a) no animal parasite eggs were found. Therefore, we are certain that the coprolites from Dust Devil Cave and Hinds Cave are human.

A coprolite is a single deposit representing only 16 consumption episodes, deposited by one individual, representing a restricted moment in time. As such, it is representative of a few meals, but not a menu. Several coprolites from the same provenance should not be taken to represent individuals, as one person is capable of depositing many coprolites over a short period of time. Interpretations at the population level, therefore, may be erroneous. Collectively, however, a large series of coprolites can reveal a menu. This is possible if the series is collected in such a way as to minimize the possibility of sampling one individual repeatedly over a short period of time (Reinhard, 1996).

In the case of this analysis, we reduced the possibility of repeatedly sampling a single individual by diversifying the samples. Coprolites were sampled from distinct strata (Shafer \& Bryant, 1977; Williams-Dean, 1978; Reinhard, 1985a; Reinhard et al., 1985; Van Ness, 1986). Then the pollen, fungal, phytolith, and macrofloral components were analyzed to ensure that each 
coprolite represented a distinct dietary profile (Williams-Dean, 1978; Reinhard, 1985a; Reinhard et al., 1985a; Van Ness, 1986).

We believe that the coprolites represent community subsistence behavior. Both caves were used by no more than 10-25 people (Shafer \& Bryant, 1977; Reinhard et al., 1985; Shafer, 1986). Artifacts and features within the caves indicate activities associated with both men and women. Therefore, we can assume that the sample was optimally diversified to increase as much as possible the chance of sampling coprolites from as many distinct males and females as possible.

Because of the care in selection of samples, the interpretations in this study address a community-level, long-term plan of action, practiced consistently over time (i.e., hunting strategy). We do not presume that our coprolite assemblages are representative of all meals that all members of the communities consumed over an extended period of time, but rather they represent samples of individuals from different generations of hunter-gatherers who occupied the caves, and participated in small animal harvests. Pollen analysis shows that these sites were used differently on a seasonal basis. Dust Devil Cave was used in colder seasons. Pollen and macroscopic remains from Hinds Cave represents plant food available from spring to autumn.

In this study, we compare the hunting strategies inferred from coprolite analysis with those inferred from zooarcheological analysis of middens.

\section{Zooarcheology of Hinds Cave: coprolites and midden}

Hinds Cave (Williams-Dean, 1978) is located approximately $2 \mathrm{~km}$ from the Pecos River in Still Canyon, west Texas (Shafer \& Bryant, 1977). It has three distinct environmental zones in the immediate vicinity of the cave (Lord, 1984). Hinds Cave was occupied from $7000 \mathrm{BC}$ to about AD 1000. Analysis of coprolites from different stratigraphic levels (Williams-Dean, 1978; Stock, 1983; Reinhard, 1988; Edwards, 1990) indicates a general continuity of diet, not strongly affected by climate changes after the Pleistocene, during the Holocene. Still Canyon provides a water source for the cave and supports a riparian environment. Desert plant resources are available immediately on top of the canyon. Midden material from the site contains fragments of Agave, Opuntia (prickly pear), Dasylirion (sotol), vegetative tissue and fruit fragments of Opuntia, and fruits or seeds of Celtis (hackberry), Prosopis (mesquite), Juglans (walnut), Quercus (oak) and Diospyros (persimmon). Pollen and vegetal macrofossil evidence suggests a warm season occupation of the cave from spring to autumn (Reinhard, 1988).

Zooarcheological analysis of bones at Hinds Cave (Lord, 1984) not associated with coprolites indicates that deer provided the majority of meat consumed, although lagomorphs and rodents were also eaten (Table 2 presents common names). In addition, birds, reptiles and fish were consumed at the cave (Tables 2 , 3 , and 4). Fish were consumed during the entire occupation of the cave except at the earliest occupation levels. In the earlier occupations of the cave, lagomorphs, rodents, carnivores and birds were more commonly eaten. Reptiles were consumed throughout the occupation at essentially the same frequency (Lord, 1984).

Importantly, the coprolites show that small animal taxa formed a significant contribution to the Hinds Cave diet (Table 5). A wide variety of small mammals, amphibians and reptiles were eaten. Thus, the coprolite data indicate more utilization of small animals than indicated by the midden zooarcheological data.

\section{Zooarcheology of Dust Devil Cave: copro- lites and midden}

At Dust Devil Cave, for one to three miles in any direction, the flat land in the immediate environment today is covered with blackbrush, with tiny microenvironments created by the presence of isolated hummocks of bedrock such as the one containing Dust Devil Cave. Within a few hours walk, however, one can get to four of Merriam's Life Zones (Brown, 1982), and the same was undoubtedly true at the end of the Pleistocene although the life zones were about $300 \mathrm{~m}$ $(1000 \mathrm{ft})$ lower. The occupation of the cave, archaeo- 
Table 2. Common names and scientific names for animals represented by archaeological bone found in Hinds Cave and Dust Devil Cave

\begin{tabular}{|c|c|}
\hline Scientific name & Common name \\
\hline Aplodinotus & Freshwater drum \\
\hline Aves & Vertebrate class of birds \\
\hline Bassariscus & Ringtail cat \\
\hline Canis & Dog or coyote \\
\hline Castor & Beaver \\
\hline Cervis & Elk \\
\hline Chrysemys & Painted turtle \\
\hline Citellus & Thirteen-lined ground squirrel \\
\hline Colinus & Quail or bob white \\
\hline Cricitidae & Rodents of the family Cricetidae \\
\hline Dipodomys & Kangaroo rat \\
\hline Erethizon & Porcupine \\
\hline Felinae & Cat family \\
\hline Felis concolor & Wild cat \\
\hline Geomyidae & Pocket gopher family \\
\hline Geomys & Pocket gopher \\
\hline Ictiobus & Probably small-mouthed buffalo fish \\
\hline Insectivora & Insectivore order \\
\hline Lepisosteus & Gar fish \\
\hline Lepus & Jack rabbit \\
\hline Mammalia & Bones identifiable only as mammal \\
\hline Marmota & Marmot \\
\hline Mephitis & Striped skunk \\
\hline Moxostoma & Sucker fish \\
\hline Neotoma & Woodrat \\
\hline Odocoileus & Deer \\
\hline Ondatra & Muskrat \\
\hline Onychomys & Grasshopper mouse \\
\hline Ovis canadensis & Bighorn sheep \\
\hline Perognathus & Pocket mouse \\
\hline Peromyscus & Deer mouse and white-footed mouse \\
\hline Phrynosoma & Horned lizards \\
\hline Procyon & Raccoon \\
\hline Pylodictus & Flathead catfish \\
\hline Rana & Frog \\
\hline Rodentia & Rodent order of mammals \\
\hline Sceloporus & Desert spiny lizard \\
\hline Sciurus & Squirrel \\
\hline Sigmodon & Cotton rat \\
\hline Spermophilus & Ground squirrel \\
\hline Spilogale & Spotted skunk \\
\hline Sylvilagus & Cotton tail rabbit \\
\hline Tamias & Chipmunk \\
\hline Thomomys & Pocket gopher \\
\hline Trionyx & Softshell turtle \\
\hline Unidentifiable & Bone could not be identified to any taxon \\
\hline Urocyon & Fox \\
\hline Zenaidura & Dove \\
\hline
\end{tabular}

logically known as the Desha Complex, dates to between 6800 and 4800 BC (Ambler, 1984; Reinhard et al., 1985). Many rodents were probably available in the summer, but Dust Devil Cave was an ideal winter habitation. The cave provided shelter from inclement weather, and there was an abundance of winter plant
Table 3. Minimal number of small animal individual determinations (MNI) for non-coprolite deposits from Hinds Cave; data derived from Lord (1984) and Gilbert (1984)

\begin{tabular}{|c|c|c|}
\hline Taxa & $\begin{array}{r}\text { MNI in } \\
\text { Hinds Cave } \\
\text { midden }\end{array}$ & $\begin{array}{r}\text { MNI in Dust } \\
\text { Devil Cave } \\
\text { midden }\end{array}$ \\
\hline Bassariscus & 4 & 0 \\
\hline Castor & 1 & 0 \\
\hline Chrysemys & 1 & 0 \\
\hline Citellus & 0 & 2 \\
\hline Colinus & 19 & 0 \\
\hline Dipodomys & 1 & 4 \\
\hline Dutamias & 0 & 3 \\
\hline Erethizon & 1 & 0 \\
\hline Geomyidae & 10 & 0 \\
\hline Geomys & 1 & 0 \\
\hline Ictiobus & 2 & 0 \\
\hline Insectivora & 0 & 1 \\
\hline Lepisosteus & 1 & 0 \\
\hline Lepus & 22 & 6 \\
\hline Marmota & 0 & 1 \\
\hline Mephitis & 1 & 0 \\
\hline Moxostoma & 1 & 0 \\
\hline Neotoma & 100 & 0 \\
\hline Ondatra & 14 & 0 \\
\hline Onychomys & 3 & 0 \\
\hline Perognathus & 3 & 1 \\
\hline Peromyscus & 19 & 4 \\
\hline Phrynosoma & 5 & 0 \\
\hline Pilodictus & 2 & 0 \\
\hline Procyon & 3 & 0 \\
\hline Putra & 1 & 0 \\
\hline Rana & 1 & 0 \\
\hline Sciurus & 1 & 0 \\
\hline Sigmodon & 56 & 0 \\
\hline Small bird & 11 & 0 \\
\hline Spermophilus & 20 & 0 \\
\hline Spilogale & 2 & 0 \\
\hline Sylvilagus & 47 & 57 \\
\hline Thomomys & 18 & 12 \\
\hline Trionyx & 6 & 0 \\
\hline Urocyon & 5 & 0 \\
\hline Zenaidura & 6 & 0 \\
\hline Total small animal & 399 & 109 \\
\hline
\end{tabular}

Table 4. Large animal individual determinations (MNI) for noncoprolite deposits from Hinds Cave (data derived from Lord, 1984)

\begin{tabular}{lrr}
\hline Taxa & $\begin{array}{r}\text { MNI in Hinds } \\
\text { Cave midden }\end{array}$ & $\begin{array}{r}\text { MNI in Dust Devil } \\
\text { Cave midden }\end{array}$ \\
\hline Felis concolor & 1 & 0 \\
Odocoileus & 7 & 2 \\
Cervis & 0 & 2 \\
Canis & 10 & 2 \\
Ovis canadensis & 0 & 2 \\
Total large animal & 18 & 8 \\
\hline
\end{tabular}


Table 5. Number of coprolites from caves exhibiting the given taxa or combinations of taxa (32 Hinds Cave coprolites contained more than one taxon; 3 Dust Devil Cave coprolites contained more than one taxon)

\begin{tabular}{|c|c|c|}
\hline Taxa & $\begin{array}{r}\text { Hinds } \\
\text { Cave } n \\
\text { (of 100) }\end{array}$ & $\begin{array}{r}\text { Dust Devil } \\
\text { Cave n } \\
\text { (of 100) }\end{array}$ \\
\hline Aplodinotus \& mammal & 1 & \\
\hline Aplodinotus \& rodent & 1 & \\
\hline Bird & & 1 \\
\hline Citellus & 3 & \\
\hline Colinus & 1 & \\
\hline Cricitidae & & 1 \\
\hline Dipodomys & & 1 \\
\hline Felinae & & 1 \\
\hline Fish & 1 & \\
\hline Fish \& Odocoileus & 1 & \\
\hline $\begin{array}{l}\text { Ictalusrus/Pylodictus } \\
\text { \& mammal }\end{array}$ & 1 & \\
\hline Lepus \& bird & 2 & \\
\hline Lepus \& rodent & 2 & \\
\hline Lepus (?) & 1 & \\
\hline Lepus, Procyon, Urocyon \& rodent & 1 & \\
\hline Lizard & & 2 \\
\hline Mammal & 6 & \\
\hline Neotoma & 5 & \\
\hline Neotoma \& bird & 1 & \\
\hline Neotoma \& fish & 1 & \\
\hline Neotoma \& Lepus & 1 & \\
\hline Neotoma \& Sigmodon & 3 & \\
\hline Neotoma \& Sylvilagus & 1 & \\
\hline Neotoma, lizard \& fish & 1 & \\
\hline Neotoma, Rana \& bird & 1 & \\
\hline Neotoma, Sigmodon \& bird & 1 & \\
\hline Neotoma, Sigmodon, lizard \& fish & 1 & \\
\hline Neotoma, Sylvilagus, lizard \& fish & 1 & \\
\hline Neotoma, Zenaidura \& bird & 1 & \\
\hline Peromyscus & 1 & \\
\hline Peromyscus \& fish & 1 & \\
\hline Procyon & 1 & \\
\hline Procyon, rodent \& bird & 1 & \\
\hline Rodent & 21 & 2 \\
\hline Rodent \& bird & 2 & \\
\hline Rodent \& fish & 1 & \\
\hline Rodent \& snake & 1 & \\
\hline Sceloporus, fish \& rodent & 1 & \\
\hline Sigmodon & 7 & \\
\hline Snake & 1 & \\
\hline Sylvilagus & 1 & 21 \\
\hline Sylvilagus \& bird & & 1 \\
\hline Sylvilagus \& large mammal & & 1 \\
\hline Sylvilagus \& rodent & 1 & 1 \\
\hline Sylvilagus, Onchomys \& fish & 1 & \\
\hline $\begin{array}{l}\text { Sylvillagus, Sigmodon \& } \\
\text { Ondatra }\end{array}$ & 1 & \\
\hline Unidentifiable & 12 & 26 \\
\hline Zenaidura & 1 & \\
\hline No bone & 3 & 42 \\
\hline
\end{tabular}

food, Opuntia, nearby. The Desha people ate so much Opuntia that after several winters these food sources would have been largely depleted (Van Ness, 1986). The rabbit supply in the immediate vicinity of the cave would probably also be depleted after several winter occupations, so the Desha people may have alternated winter camps every year or decade, sometimes spending the winter in Sand Dune Cave to the south and $285 \mathrm{~m}$ higher. In the case of Dust Devil Cave, climatic differences are accentuated by the fact that the occupation was at the end of the Pleistocene, with moister and cooler conditions than those of today.

Dust Devil Cave is located at an elevation of 1,495 m (4,900 ft) between Navajo Mountain and the San Juan River near the southern border of Utah. It is a deep but narrow cave and its small size precludes comfortable habitation by more than a dozen people (Reinhard et al., 1985). The surrounding, level terrain is now vegetated almost entirely by blackbrush (Acacia), but at the time the cave was occupied, local vegetation included Celtis (hackberry), Quercus (oak), Pinus edulis (piñon), Juniperus (juniper) and Opuntia (prickly pear cactus) in quantity, based on the analysis of cave deposits. Slightly to the east (1 $\mathrm{km}$ ) is the incised canyon of Desha Creek, which is today a permanent stream and was undoubtedly lush at 6000 BC. The San Juan River canyon is $6-7 \mathrm{~km}$ north of the site. At the same distance to the southeast start the slopes of Navajo Mountain, gradually rising to $3,150 \mathrm{~m}$.

Plants recovered from the midden of Dust Devil Cave include the dry fruits or seeds of Juniperus, Ephedra (mormon tea), Pinus edulis, grass, Chenopodium (goosefoot), Quercus, and Opuntia. Fleshy fruits recovered from the cave midden include Cucurbita spp. (non-cultivated squash), Shepherdia (buffalo berry), Astragalus (vetch), Amelanchier, Celtis, and Yucca. Pot herbs and stems from the midden include Allium (wild onion), Eriogonum (wild buckwheat), and Apiaceae (parsley family) (Richard H. Hevly, unpublished data). Many of these plants become available for consumption in the autumn.

Compared with the Dust Devil Cave midden, only a limited number of pollen and macrofossil types were 
recovered from the coprolites. The plant foods from the coprolites consist mainly of Opuntia pad fragments, Chenopodium seeds, fibers from desert succulents, parched Sporobolus (drop-seed) caryopses, sunflower achenes, wild onion bulbs and piñon pine nuts (Van Ness, 1986; Hansen, 1994: 104). Very few background pollen types were present (Reinhard, 1985a). These data suggest that the dietary remains from the coprolites reflect a diet low in plant food diversity. Such a diet would be consistent with a cooler season occupation from late autumn through to early spring. The poor representation of background pollen in the coprolites supports this inference. It is our opinion that the Dust Devil Cave coprolites represent a cool season diet with low food diversity both in plants and animals.

Non-coprolite faunal remains indicate that the inhabitants of Dust Devil Cave specialized in the hunting of cottontail rabbits (Tables 3 and 4). Large numbers of Sylvilagus bones were scattered within the Dust Devil Cave midden deposits. Odocoileus hemionus (mule deer), Canis latrans (coyote) and Ovis canadensis (mountain sheep) bones were also found in the midden in low numbers. The presence of subadult sheep and rabbits indicates a late spring occupation (Gilbert, 1984). The zooarcheological analysis of Dust Devil Cave indicates that the meat consumption was composed largely of small animals, especially cottontail rabbits, with limited exploitation of large animals. Of the midden bone, $90 \%$ exhibited the appearance of boiled bone (Gilbert, 1984). Boiling is done to remove bone grease which is calorie-rich. It would thus appear that the animal remains were processed at Dust Devil Cave to recover as much nourishment as possible.

\section{Comparison of midden and non-midden data between sites}

The availability of both coprolite and midden remains from both sites allows for a comparison of coprolite and non-coprolite zooarcheological assemblages with respect to small animal consumption. The coprolite bone remains from Dust Devil cave are dominated by rabbits (Tables 3-6). Thus, for Dust Devil Cave, the midden data and coprolite data present the same
Table 6. Identifiable Sylvilagus and Rodentia element fragments found in Dust Devil Cave coprolites (from Czaplewski, 1985)

\begin{tabular}{lrr}
\hline Element & Sylvilagus & Rodentia \\
\hline Tooth & 5 & 2 \\
Cranial & 4 & 1 \\
Cervical vertebrae & 9 & 0 \\
Thoracic vertebrae & 11 & 0 \\
Lumbar vertebrae & 4 & 1 \\
Caudal vertebrae & 1 & 0 \\
Unknown vertebrae & 1 & 4 \\
Pelvis & 3 & 1 \\
Ribs & 12 & 0 \\
Clavicle & 0 & 1 \\
Humerus & 3 & 4 \\
Radius & 0 & 2 \\
Ulna & 1 & 1 \\
Femur & 1 & 0 \\
Tibia & 1 & 0 \\
Tarsal/carpal & 9 & 1 \\
Phalange & 2 & 0 \\
\hline
\end{tabular}

picture of animal exploitation that focused largely on rabbits. At Dust Devil Cave, predominantly Sylvilagus bone was recovered in both the coprolite and noncoprolite faunal assemblages. Therefore, both lines of evidence indicate that animal consumption at Dust Devil Cave was specialized.

At Hinds Cave, more genera of small animals are present in the non-coprolite faunal assemblage than in coprolites (Tables 3-5). This shows that some small animal meat was eaten off the bone. Both Hinds Cave assemblages are diverse. Thus, it appears that small bone recovered from coprolites reflects the patterns in small animal exploitation as represented by zooarcheological data recovered from the cave midden. However, the evidence of small animals is higher in the Hinds Cave coprolites.

\section{Ecological and behavioral comparisons}

The bone data from Dust Devil Cave and Hinds Cave indicate very different small-animal exploitation strategies as indicated by the following observations (Table 7). For Dust Devil Cave, 35 taxa identifications were made from the 32 coprolites that contained bone identified to some taxonomic level. At a general level, 31 $(88 \%)$ of the taxa identified in the Dust Devil Cave 
coprolites are terrestrial mammals and 24 (69\%) are Sylvilagus. Bird and reptile remains each make up 6\% $(n=2)$ of the identifiable assemblage. Although available nearby today, no aquatic animals are present in the assemblage. Of 85 identifiable bone elements found in the coprolites (Table 6), 67 (79\%) are from Sylvilagus.

Hinds Cave exhibits a more diverse small-animal harvesting strategy. Mammals make up $67 \%$ of the assemblage, birds $12 \%$, reptiles $7 \%$, amphibians $1 \%$, and fish $13 \%$. Of the mammals identified to order, $70 \%$ are rodents, $24 \%$ are lagomorphs, and $6 \%$ are carnivores. Of the genera identified, Neotoma makes up 29\% of the assemblage, Sigmodon 20\%, and Lepus and Sylvilagus make up $10 \%$ each. The other genera are represented by the following: Procyon and Spermophilus 5\% each; Peromyscus, Zenaidura, and Aplodinotus 3\% each; Ondatra, Onchomys, Urocyon, Colinus, Sceloporus, and Ictalusrus 2\% each.

A greater diversity of animals was utilized at Hinds Cave in comparison with Dust Devil Cave (Table 7). Sixteen genera are identified from Hinds Cave

Table 7. The number of coprolites containing bone of the given taxa from Dust Devil Cave and Hinds Cave

\begin{tabular}{lrr}
\hline Taxon & Hinds Cave & Dust Devil Cave \\
\hline Unidentifiable & 12 & 26 \\
Aplodinotus & 2 & 0 \\
Aves & 9 & 2 \\
Citellus & 3 & 0 \\
Colinus & 1 & 0 \\
Cricitidae & 0 & 1 \\
Dipodomys & 0 & 1 \\
Felinae & 0 & 1 \\
Ictalusrus/Pylodictus & 1 & 0 \\
Lepus & 7 & 0 \\
Lizard & 3 & 2 \\
Mammalia & 9 & 1 \\
Neotoma & 18 & 0 \\
Odocoileus & 1 & 0 \\
Ondatra & 1 & 0 \\
Osteichthes & 10 & 0 \\
Peromyscus & 2 & 0 \\
Procyon & 3 & 0 \\
Rana & 1 & 0 \\
Rodentia & 32 & 3 \\
Sceloporus & 1 & 0 \\
Sigmodon & 13 & 0 \\
Snake & 2 & 0 \\
Sylvilagus & 2 & 0 \\
Urocyon & 1 & 0 \\
Zenaidura & & 0 \\
\hline
\end{tabular}

coprolites, but only two genera are identified from Dust Devil Cave coprolites. Given that the environments of both caves sustained a large diversity of animal food resources, the data indicate variation in selection strategies. We conclude that the lower diversity in Dust Devil Cave coprolites indicates that the prehistoric inhabitants were specialized in their small animal procurement. Sylvilagus (cottontail rabbit) was the animal most often hunted. In contrast, the inhabitants of Hinds Cave consumed a wide variety of small animals including terrestrial, amphibious and aquatic genera.

Another indicator of small animal food diversity is the proportion of coprolites that contain two or more taxa. Three Dust Devil Cave coprolites contained two or more taxa, compared with Hinds Cave where 32 coprolites contained two or more taxa.

The difference in the variety of animals in the coprolites between the two sites is due largely to the fact that the coprolites from Dust Devil Cave reflect cold season subsistence and those from Hinds Cave reflect warm weather subsistence. During cold weather, Dust Devil Cave inhabitants concentrated their small animal harvesting on lagomorphs, since rodents are notably absent in winter in the area of Dust Devil Cave. In contrast, at Hinds Cave, the greater variety of animals present during the warm season occupation resulted in a more diversified hunting strategy.

\section{Food preparation of small animals}

The coprolite data also address food preparation techniques. At Dust Devil Cave, most of the Sylvilagus elements found in coprolites were from the vertebral column and rib cage (Table 6). Other elements include cranial fragments and appendicular bones. This indicates that all parts of rabbits were eaten. The fact that vertebrae are more common than other observed elements is simply due to the fact that vertebrae are the most plentiful element in the skeleton. Fungal spore analysis of coprolites (Reinhard, 1985a: 121-3) revealed the spores of certain fungal organisms that are eaten by rabbits and rodents. The presence of these spores in human coprolites indicates that rabbit viscera were eaten and supports the infer- 
ence that rabbits were eaten completely. In contrast, a large proportion of rodent elements (41\%) are from the appendicular skeleton. This may indicate a preference for rodent limbs. However, there are very few identifiable rodent bones $(n=17)$ compared with identifiable Sylvilagus elements $(n=67)$; perhaps this difference is more likely to be due to the fact that the vertebrae of extremely small mammals are digested, as demonstrated experimentally by Crandall and Stahl (1995).

The methods of preparation of small animals for consumption at Dust Devil Cave are indicated by the condition of bone derived from the coprolites. Of all bone fragments found in the coprolites from Dust Devil Cave $(n=96)$, only three are charred. This indicates that the majority of the bone was not directly exposed to fire. If the meat from these small animals was cooked at all, it is probable that whole animals were cooked, divided, and eaten. The find of rabbit hair in macrofossil remains from Dust Devil Cave (Reinhard, 1985a: 112-13) indicates that some animals may not have been cooked at all. At both sites, bones are highly fractured, and pieces of the same bone are rarely found in the same coprolite, indicating pre-ingestion fracturing. It would appear that the Desha people at Dust Devil Cave ate rabbit legs more-or-less whole, then pounded the rest of the carcass before eating it.

\section{Ethnographic comparisons}

Prehistoric small-animal procurement strategies may have resembled those reported ethnographically. The consumption of wood rats (Neotoma spp.), also known as pack rats, has been noted ethnographically. They were regarded as good food by the Yaqui (Spicer, 1954: 49), constituted a staple for all tribes along the lower Colorado River (Castetter \& Bell, 1951: 217), and many were eaten by the Tohono O'Odham. The Cocopah set fire to their nests, clubbing the rats as they emerged, undoubtedly fragmenting some bone in the process. The same technique has been noted at Santa Clara. The fire method of hunting wood rats could be easily done in winter and summer, so it is tempting to think that the paucity of wood rats at Dust Devil Cave compared with Hinds Cave is due to the lack of suitable nesting places and lack of food for wood rats. The only wood rat noted in the 1970s within a kilometer of Dust Devil Cave was in a crack in Navajo Sandstone about $50 \mathrm{~m}$ to the west of the Dust Devil Cave outcrop. This nest had burned. Co-author J.R.A. assumed that it had been burned in the early 1970s, since Navajos had been observed burning wood rat nests and clubbing the animals. However, in a piñon-juniper environment, nesting places in and around old dead trees are plentiful, so more wood rats may have been present near Dust Devil Cave at the end of the Pleistocene. Potential wood rat food and nest sites are now much more plentiful in the vicinity of Hinds Cave in comparison with Dust Devil Cave.

Wood rats must have been an abundant food for the inhabitants of Hinds Cave. Eating so many would have meant ever-widening foraging for wood rats, or careful management of this resource by avoiding hunting in some areas in some years.

Rabbits are often hunted by surrounding or drives, and killed by clubbing or with heavy throwing sticks. Rabbits not eaten immediately can be dried and stored for the winter, as was done by the northern Paiute (Fowler \& Liljeblad, 1986: 439). During the winter the entire carcass, including the bones, was either stoneboiled or pounded into fragments to make a soup. The bones from wood rats were considered so good that they were saved, pounded and eaten by the Yumans along the lower Colorado River (Castetter \& Bell, 1951: 217). Since both killing and processing methods for small animals result in fragmented bones, it is no wonder that bones from coprolites are so severely fragmented.

\section{Chemical analyses in coprolite studies}

Zooarcheological bone analysis of coprolites is biased towards small animals: a bias that is the reverse of zooarcheological analysis of middens. Bones are not the only animal residue recovered from coprolites. Protein residue analysis of coprolites from Antelope House showed that both small and large mammals were eaten (Sutton \& Reinhard, 1995), demonstrating that large animal consumption could be verified us- 
ing biochemical means. Most recently, myoglobin has been used to identify human muscle residue in a purported cannibal coprolite, as reviewed by Marler et al. (2000). The interesting aspect of myoglobin analysis is that myoglobin is only present in muscle. Therefore it signals consumption of meat. If this technique can be developed beyond a search for human tissue, it may become an important means of identifying other animal meat in coprolites.

The importance of biochemical assays of coprolites for meat residues lies in the fact that small animal bones are largely digested before defecation. This factor leads to an underestimation of dietary meat reliance in coprolite analysis. This is especially true of fish bone, the majority of which is digested in the intestinal tract (Jones, 1986).

One recent dietary debate emerged from the conflicting dietary reconstructions from bone chemistry and coprolite analysis for Chinchorro mummies (reviewed by Reinhard, 1998). Strontium isotope analysis indicated a high reliance on marine food sources (Arriaza, 1995), while coprolite analysis indicated a moderate reliance on marine resources (Reinhard \& Bryant, 1992b). This discrepancy possibly stems from the loss of bone in coprolites due to digestion (Reinhard \& Bryant, 1992b; Reinhard, 1998). Strontium isotope analysis of bone from Chinchorro mummies reflects a very high degree of reliance on marine resources that was not represented in the coprolites. Therefore the use of zooarcheological and biochemical analyses of coprolites must be combined for a complete picture of meat consumption in prehistory.

\section{Conclusions}

The analyses presented here indicate that bone in coprolites has great interpretative value. However, a variety of factors influence the utility of faunal analysis at any given site. Our purpose here was to suggest that a partnership between the fields of zooarcheology and coprolite studies is needed to understand better the subsistence patterns of prehistoric peoples.

The results of the analyses presented above are very promising. The study of bones in coprolites between hunter-gatherer sites shows that comparative, signif- icant analyses can be completed. Furthermore, these studies make possible inferences about small animal procurement strategies and dietary importance.

The detailed comparative analysis of coprolite bone from Hinds Cave and Dust Devil Cave has greater ramifications. It is clear that if faunal analysis of coprolites is properly done, detailed information reflecting both environment and hunting strategy can be retrieved. Coprolite-derived bone is an under-utilized interpretative tool. It is hoped that zooarcheologists in the future take a greater interest in coprolite faunal remains and fully describe such data in their reports. Future work should also incorporate biochemical assays in conjunction with bone studies to flesh out more fully the nature of prehistoric animal use.

\section{Acknowledgements}

We appreciate the comments of an anonymous reviewer for the International Journal of Osteoarchaeology, which were addressed in the final revision of this manuscript.

\section{References}

Aasen DK. 1984. Pollen, Macrofossil, and Charcoal Analyses of Basketmaker Coprolites from Turkey Pen Ruin, Cedar Mesa, Utah. MA thesis, Washington State University, Pullman.

Ambler JR. 1984. The Desha Complex: pre-altithermal adaptation at Dust Devil Cave, Utah. Proceedings of the 19th Great Basin Anthropological Conference Symposium.

Arriaza BE. 1995. Beyond Death: the Chinchorro Mummies of Ancient Chile. Smithsonian Institution Press: Washington, DC.

Billman BR, Lambert PM, Banks LL. 2000. Cannibalism, warfare, and drought in the Mesa Verde Region during the twelfth century A.D. American Antiquity 65: 145-178.

Brown DE. 1982. Biotic communities of the American Southwest United States and Mexico. Desert Plants 4: 1-4.

Bryant VM Jr., 1974a. Prehistoric diet in southwest Texas: the coprolite evidence. American Antiquity 39: 407-420.

Bryant VM Jr., 1974b. The role of coprolite analysis in archaeology. Bulletin of the Texas Archaeological Society 45: 1-48.

Bryant VM Jr., Williams-Dean G. 1975. The coprolites of man. Scientific American 232: 100-109. 
Callen EO. 1963. Diet as revealed by coprolites. In Science in Archaeology, Brothwell D, Higgs E (eds). Thames and Hudson: London; 186-194.

Callen EO, Cameron TWM. 1960. A prehistoric diet revealed in coprolites. New Scientist 8: 35-40.

Castetter EF, Bell WH. 1951. Yuma Indian Agriculture; Primitive Subsistence on the Lower Colorado and Gila Rivers. University of New Mexico Press: Albuquerque.

Chame M. 2003. Terrestrial mammal feces: a morphometric summary and description. Memorias do Instituto do Oswaldo Cruz 98: 71-94.

Clary KH. 1983. Prehistoric Coprolite Remains from Chaco Canyon, New Mexico: Inferences for Anasazi Diet and Subsistence. MSc thesis, University of New Mexico, Albuquerque.

Clary KH. 1984. Anasazi diet and subsistence as revealed by coprolites from Chaco Canyon. In Recent Research on Chaco Prehistory, Judge WL, Schelberg JD (eds). National Park Service: Albuquerque; 265-276.

Crandall B, Stahl P. 1995. Human digestive effects on a micromammalian skeleton. Journal of Archaeological Science 22: 789-797.

Czaplewski N. 1985. Bone remains from the Dust Devil Cave Feces. Appendix J. In Recovery of Helminths from Prehistoric Feces; The Cultural Ecology of Ancient Parasitism, Reinhard KJ. MSc thesis, Northern Arizona University, Flagstaff, US.

Dongoske KE, Martin DL, Ferguson TJ. 2000. Critique of the claim of cannibalism at Cowboy Wash. American Antiquity 65: 179-190.

Edwards SK. 1990. Investigations of Late Archaic Coprolites: Pollen and Macrofossil Remains from Hinds Cave (41VV456), Val Verde County, Texas. MA thesis, Texas A\&M University, College Station, TX.

Fowler CS, Liljeblad S. 1986. Northern Paiute. In Handbook of North American Indians 11, D'Zaevedo WL (ed.). Smithsonian Institution: Washington, DC; 435-465.

Fry GF. 1977. Analysis of Prehistoric Coprolites from Utah. University of Utah Anthropological Papers 97. University of Utah Press: Salt Lake City.

Fry GF. 1980. Prehistoric diet and parasites in the desert west of North America. In Early Native Americans, Browman DL (ed.). Mouton Press: The Hague; 325-339.

Fry GF. 1985. Analysis of fecal material. In The Analysis of Prehistoric Diet, Gilbert RI Jr. Mielke JH (eds). Academic Press: New York; 127-154.

Gilbert GM. 1984. A re-examination of faunal material from Dust Devil Cave: old data, new interpretation. Proceedings of the 19th Great Basin Anthropological Conference.
Guerra RMSNC, Gazêta GS, Amorim M, Duarte AN, SerraFreire NM. 2003. Ecological analysis of acari recovered from coprolites from archaeological site of northeast Brazil. Memorias do Instituto do Oswaldo Cruz 98: 181-190.

Hall HJ. 1972. Diet and Disease at Clyde’s Cavern, Utah: As Revealed via Paleoscatology. MA thesis, University of Utah, Salt Lake City.

Hansen E. 1994. Early Archaic Diet at Old Man Cave: A Perspective on Archaic Subsistence in Southeastern Utah. MA thesis, Department of Anthropology, Northern Arizona University, Flagstaff, US.

Haury EW. 1976. Hohokam: Desert Farmers and Craftsmen. University of Arizona Press: Tucson.

Heizer RF. 1967. Analysis of human coprolites from a dry Nevada cave. In Papers on Great Basin Archaeology, Heizer RF (ed.). Reports of the University of California Survey Reports 70: Berkeley, CA; 1-20.

Heizer RF, Napton IK. 1969. Biological and cultural evidence from prehistoric human coprolites. Science 165: 563-568.

Holloway RG. 1985. Diet and medicinal plant usage of a late Archaic population from Culberson County, Texas. Bulletin of the Texas Archaeological Society 54: 319-329.

Iñiguez AM, Araújo A, Vicente ACP, Ferreira LF, Reinhard KJ. 2003a. Enterobius vermicularis: specific detection by amplification of an internal region of $5 \mathrm{~S}$ ribosomal RNA intergenic spacer and trans-splicing leader RNA analysis. Experimental Parasitology 102: 118-122.

Iñiguez AM, Reinhard KJ, Araújo A, Ferreira LF, Vicente ACP. 2003b. Enterobius vermicularis ancient DNA from north and south american human coprolites. Memorias do Instituto do Oswaldo Cruz 98: 67-69.

Jones AKG. 1986. Fish bone survival in the digestive systems of the pig, dog, and man: some experiments. In Fish and Archaeology: Studies in Osteometry, Taphonomy, Seasonality, and Fishing Methods. BAR International Series 294: Oxford; 53-61.

Lambert PM, Banks LL, Billman BR, Marlar RA, Newman ME, Reinhard KJ. 2000. Response to the critique of the claim of cannibalism at Cowboy Wash. American Antiquity 65: 397-406.

Lindsay AJ Jr. Ambler JR, Stein MA, Hobler PM. 1968. Survey and Excavations North and East of Navajo Mountain, Utah, 1959-1962. Museum of Northern Arizona Bulletin 45: Flagstaff, AZ.

Lord KJ. 1984. The zooarcheology of Hinds Cave, Val Verde County, Texas. MA thesis, Texas A\&M University, College Station, TX.

Marlar R, Billman B, Banks L, Lambert P, Reinhard K. 2000. Fecal evidence of cannibalism. Southwestern Lore 4: 14-22. 
Moore JG, Fry GF, Englert E. 1969. Thorny-headed worm infection in North American prehistoric man. Science 163: 1324-1325.

Poinar HN, Kuch M, Sobolik KD, Barnes I, Stankiewicz AB, Kuder T, Spaulding WG, Bryant VM, Cooper A, Pääbo S. 2001. A molecular analysis of dietary diversity for three Archaic Native Americans. Proceedings of the National Academy of Sciences 98: 4317-4322.

Reinhard KJ. 1985a. Recovery of Helminths from Prehistoric Feces; The Cultural Ecology of Ancient Parasitism. MSc thesis, Northern Arizona University, Flagstaff, AZ.

Reinhard KJ. 1985b. Strongyloides stercoralis in the prehistoric Southwest. In Health and Disease in the Prehistoric Southwest, Merbs CF, Milner RJ (eds). Arizona State University Anthropological Research Paper 34: Tempe; 234-243.

Reinhard KJ. 1988. Diet, Parasitism and Anemia in the Prehistoric Southwest. PhD thesis, Texas A\&M University, College Station, TX.

Reinhard KJ. 1992. Patterns of diet, parasitism, and anemia in prehistoric west North America. In Diet, Demography, and Disease: Changing Perspectives on Anemia, StuartMacadam P, Kent S (eds). Aldine de Gruyter: New York; 219-258.

Reinhard KJ. 1996. Parasite ecology of two Anasazi villages. In Case Studies in Environmental Archaeology, Reitz EJ, Newson LA, Scudder SJ (eds). Plenum Press: New York; 175-194.

Reinhard KJ. 1998. Mummy studies and paleonutrition. In Mummies, Disease, and Ancient Cultures, Cockburn E, Reyman T (eds). Cambridge University Press: Cambridge; 372-377.

Reinhard KJ, Bryant VM. 1992a. Coprolite analysis: a biological perspective on archaeology. In Advances in Archaeological Method and Theory 4, Schiffer MB (ed.). University of Arizona Press: Tucson; 245-288.

Reinhard KJ, Bryant VM. 1992b. Investigating mummified intestinal contents: reconstructing diet and parasitic disease. In Actas del I Congreso Internacional de Estudos sobre Momias(Proceedings of the 1st World Congress on Mummy Studies). Museo Arqueologico y Etnografico de Tenerife: Tenerife; 403-408.

Reinhard KJ, Danielson DR. 2005. Pervasiveness of phytoliths in prehistoric southwestern diet and implications for regional and temporal trends for dental microwear. Journal of Archaeological Science 32: 981-988.

Reinhard KJ, Ambler JR, McGuffie M. 1985. Diet and parasitism at Dust Devil Cave. American Antiquity 50: 819-824.

Reinhard KJ, Araújo A, Ferreira LF, Herrmann B. 1986. Recovery of parasite remains from coprolites and latrines: aspects of paleoparasitological technique. Homo 37: 217-239.
Reinhard KJ, Danielson M, Daniels DR, Miranda Chaves S. 2002. Multidisciplinary coprolite analysis. In Bighorn Cave: Test Excavation of a Stratified Dry Shelter, Mojave County, Arizona, Geib PR, Keller DR (eds). Bilby Research Center Occasional Papers 1: Northern Arizona University, Flagstaff; 135-152.

Rhone A. 1971. Mug House, Mesa Verde. US Government Printing Office: Washington, DC.

Roust NL. 1967. Preliminary examination of prehistoric human coprolites from four western Nevada caves. In Papers on Great Basin Archaeology, Heizer RF (ed.). University of California Survey Reports 70: Berkeley, CA; 49-88.

Scott L. 1979. Dietary inferences from Hoy House coprolites: a palynological interpretation. The Kiva 44: 257-281.

Shafer HJ. 1986. Ancient Texans: Rock Art and Lifeways along the Lower Pecos. Texas Monthly Press: Austin, TX.

Shafer HJ, Bryant VM. 1977. Archaeological and Botanical Studies at Hinds Cave, Val Verde County, Texas. Anthropological Laboratory, Texas A\&M University, Special Series 1: College Station, TX.

Sobolik K. 1988. Diet change in the lower Pecos: analysis of Baker Cave coprolites. Bulletin of the Texas Archaeological Society 59: 111-127.

Sobolik K. 1993. Direct evidence for the importance of small animals to prehistoric diets: a review of coprolite studies. North American Archaeologist 14: 227-243.

Spicer EH. 1954. Potam, a Yaqui Village in Sonora. American Anthropological Association Memoir 77.

Stiger MA. 1977. Anasazi Diet: the Coprolite Evidence. MA thesis, University of Colorado, Boulder, CO.

Stock JA. 1983. The Prehistoric Diet of Hinds Cave (41VV456), Val Verde County, Texas: The Coprolite Evidence. MA thesis, Texas A\&M University, College Station, TX.

Sutton MQ, Reinhard KJ. 1995. Cluster analysis of the coprolites from Antelope House: implications for Anasazi diet and cuisine. Journal of Archeological Science 22: 741-750.

Szuter CR. 1991. Hunting by Prehistoric Horticulturalists in the American Southwest. Garland Publishing: New York.

Van Ness M. 1986. Desha Complex Macrobotanical Fecal Remains: An Archaic Diet in the American Southwest. MA thesis, Northern Arizona University, Flagstaff, US.

Williams-Dean G. 1978. Ethnobotany, and Cultural Ecology of Prehistoric Man in Southwest Texas. PhD thesis, Texas A\&M University, College Station, TX. 